\title{
RADOSLAW MARKOWSKI
}

Uniwersytet SWPS

ORCID: 0000-0001-6018-3409

\section{BEN STANLEY}

Uniwersytet SWPS

ORCID: 0000-0001-6932-1046

\section{POCZUCIE POLITYCZNEGO SPRAWSTWA: O DETERMINANTACH I KORELATACH ZJAWISKA*}

\section{A Sense of Political Agency: About the Determinants and Correlates of the Phenomenon}

The article deals with the issue of a sense of political agency in the context of Polish local elections. It discusses the phenomenon itself and attempts to explain its determinants and relationships with electoral participation. The issue is studied in two institutional contexts: single-mandate constituencies and proportional representation constituencies.

Keywords: sense of political agency, electoral participation, electoral regulations.

\section{ZAGADNIENIA TEORETYCZNE}

Poczucie politycznego sprawstwa (political efficacy) to pojęcie i zjawisko ważne dla empirycznie zorientowanej politologii oraz socjologii polityki, a zwłaszcza psychologii politycznej (Banducci, Donovan, Karp 1999). Jest wynikiem skomplikowanych procesów społecznych, a jednocześnie wpływa na wiele ważnych zjawisk publicznych i politycznych, wśród nich na partycypację wyborczą oraz jakość politycznego przedstawicielstwa (Anderson \& Guillroy 1997; Franklin et al.

Artykuł powstał na podstawie zrealizowanego grantu Narodowego Centrum Nauki nr 2014/13/B/HS5/02580 pt. „Wpływ reguł wyborczych na jakość demokracji lokalnej w Polsce" (kierownik grantu: Radosław Markowski). 
2004). Nie jest jednak tak, by kontekst nie miał znaczenia - w naszej analizie tym kontekstem jest obowiazujaca ordynacja wyborcza.

We współczesnej politologii przez 'poczucie politycznego sprawstwa' rozumiemy najczęściej zjawisko wiary i zaufania obywateli do władzy, rządzących w szczególności. Owa wiara i zaufanie wsparte sa przekonaniem, że obywatel rozumie procesy społeczne i publiczne i że ma na nie wpływ (Morrell 2005; Pingree 2011). Pojęcie to - i samo zjawisko - odnosi się do relacji, jaka zachodzi między ludzkimi ocenami życia publicznego i politycznego a uczestnictwem politycznym. Ta partycypacja polityczna - szeroko rozumiana - determinowana jest ogólnym poczuciem wyrafinowania we wpływaniu na otoczenie, na decyzje, na aspiracje jednostki czy na osiaganie konkretnych celów (Bandura 1991). Poczucie politycznego sprawstwa ma kilka odmian, wśród których 'wewnętrzne' i 'zewnętrzne' stanowia podstawowe rozróżnienie (Pollock 1983); pierwsza odmiana odnosi się do subiektywnego przekonania jednostek o rozumieniu i możliwości wpływania na świat polityki, ta druga - do oceny mechanizmów samego systemu politycznego.

Poczucie sprawstwa politycznego nieco inaczej wpływa np. na partycypację wyborczą w jednomandatowych okręgach wyborczych (JOW), niż gdy oddziałuje w kontekście ordynacji proporcjonalnych (PR). Tak więc, wyborcy w systemach PR, tam gdzie maja więcej opcji partyjnych do wyboru, ujawniają wyższy poziom politycznego sprawstwa i sa silniej motywowani do głosowania w dniu wyborów, niż wtedy gdy wybór jest znacznie bardziej ograniczony (Katz 1980; Downs 1957). Tego i podobnego - rodzaju wiedzę współczesna politologia czerpie głównie z badań makro oraz danych zagregowanych (Jackman \& Miller 1995; Franklin et al. 2004), dlatego tak ważne jest sprawdzenie, czy logika tego wywodu znajduje potwierdzenie na poziomie indywidualnym.

O poziomie indywidualnym wiemy ponadto, że ponieważ ordynacje większościowe nagradzaja tylko jednego wygranego (pozostali w jednomandatowych okręgach wyborczych sa przegranymi), potencjalny wpływ obywatela na politykę - jeśli ten preferuje kandydata mniejszościowego lub pozapartyjnego - jest minimalny, jeśli nie żaden. $Z$ drugiej strony, w systemach wielopartyjnych, w których proporcja poparcia obywateli dość dobrze odzwierciedla siłę danego ugrupowania w ciele przedstawicielskim, potencjalnie wszyscy wyborcy maja wpływ na to, jaka będzie ostateczna siła ich partii w parlamencie. Badania wskazują zatem jednoznacznie, iż dysproporcjonalność między preferencjami obywateli a kompozycja ciała przedstawicielskiego, cechująca głównie systemy większościowe, kreuje u obywateli poczucie marnotrawstwa 
ich głosu, jeśli nie są sympatykami kandydata większościowego. To poczucie marnotrawstwa przekłada się klarownie na wyraźnie niższa frekwencję wyborczą w systemach większościowych o jednomandatowych okręgach wyborczych (szczegóły patrz Franklin 1996).

Innymi słowy, to, czy głosujący obywatele maja subiektywne poczucie wpływu i wagi własnego głosu wyborczego, ma fundamentalny wpływ na wiele innych aspektów oceny świata polityki, w tym na aktywne w nim uczestnictwo. $Z$ wielu empirycznie zorientowanych dokonań wiemy, że nierówne (dysproporcjonalne) przekładanie głosów na mandaty niweluje poczucie sprawstwa wielu osób, co z kolei może sprzyjać decyzji o absencji wyborczej. Jest jednak jeszcze jeden czynnik kontekstowy, którego nie sposób pominąć, to cechy systemu partyjnego. Ta relacja jest skomplikowana, a wyniki empiryczne opisują sprzeczne zależności. $Z$ jednej strony mamy dane wskazujące na mechanizm redukcji poczucia sprawstwa, a w konsekwencji na wyższe prawdopodobieństwo absencji, w systemach wielopartyjnych $z$ tego powodu, że ostatecznie o tym, kto rządzi, decyduja negocjacje elit, a nie bezpośrednio wyborcy. $Z$ drugiej jednak strony, sama oferta alternatyw partyjnych wzmaga poczucie reprezentatywności systemu i przez to zwiększa poczucie sprawstwa oraz partycypację.

Światowa politologia wskazuje na jeszcze jeden mechanizm, dzięki któremu ordynacje proporcjonalne, a co za tym idzie systemy wielopartyjne cechuje wyższa partycypacja wyborcza niż ordynacje większościowe. Otóż wielopartyjność wpływa na poziom partycypacji poprzez zwiększona siłę identyfikacji partyjnej (party identification, PID), a dzieje się tak dlatego, że w systemach wielopartyjnych nie występuje tendencja dośrodkowej orientacji partii na tzw. centrowego wyborce (median voter). Krótko: nie występuje tu logika systemów dwupartyjnych polegająca na walce o centrowego wyborcę, która $z$ kolei odstrasza innych, bardziej niecentrowo ulokowanych obywateli. Co więcej, $\mathrm{w}$ systemach wielopartyjnych wyborcy maja silniejsza identyfikacje z partiami, gdyż ich większa liczba pozwala na dokładniejsza reprezentację bardziej konkretnych preferencji i oczekiwań swoich zwolenników niż w systemach dwupartyjnych zorientowanych na znacznie większe zbiorowości obywateli. W systemach tych występuja ponadto partie - mniej lub bardziej - radykalne; one maja swoich sympatyków, którzy w systemach dwupartyjnych pozostaja zdemobilizowani (Ladner, Milner 1999). $Z$ innych badan wiemy $z$ kolei, że wyborcy o silnej identyfikacji partyjnej sa bardziej zainteresowani polityka oraz bardziej skłonni brać udział w wyborach (Verba, Nie \& Kim 1978). 
Powyższy skrótowy opis dokonań badawczych dotyczy niemal wyłącznie zjawisk występujących na poziomie ogólnonarodowym, zazwyczaj w wyborach do ciał przedstawicielskich. Problem w tym, że nie wiemy, jak te ogólne zależności - w zdecydowanej większości zgromadzone w innym kontekście - odnosza się do wyborów lokalnych? Podstawowy problem dotyczy dwóch ontologicznych aspektów zagadnienia. Po pierwsze, w jakim stopniu wybory lokalne sa wyborami partyjnymi, a jeśli nie sa, to czy byty w nich startujące wykazują trwałość pozwalająca traktować ich jako funkcjonalne ekwiwalenty partii. Po drugie - i to zagadnienie chyba jest ważniejsze - jaka jest stabilność wyborczych 'regul gry', tj. prawa wyborczego, co $z$ kolei łączy się bezpośrednio $z$ ontologia czasu. Rein Taagepera przekonuje nas, iż ordynacje wyborcze ujawniaja swoje trwałe skutki dopiero po co najmniej trzech cyklach wyborczych. $Z$ drugiej strony, warto pamiętać o kluczowym rozróżnieniu zaproponowanym ponad pól wieku temu przez Maurice Duvergera (1954) na „mechaniczny” i „psychologiczny” efekt ordynacji. Ten pierwszy działa niemal natychmiast, natomiast tempo, w jakim ludzie ucza się, jakie konkretne efekty daje stosowanie np. ordynacji FPTP (first-past-the-post) westminsterskiej wersji głosowania większościa względna $\mathrm{w}$ jednomandatowych okręgach wyborczych, wymaga czasu i poza zdolnością ludzi i skutecznościa socjalizacji politycznej partii niebagatelną rolę odgrywa tu przestrzenne, strukturalne i funkcjonalne zróżnicowanie społeczeństwa. Tak czy inaczej, efekty zastosowania konkretnych instytucji politycznych oceniać można zawsze po dość znacznym czasie, gdy obywatele nabęda kompetencji w kwestii ich funkcjonowania, poznaja skutki do jakich prowadza.

\section{OPIS OGÓLNEGO ZAMYSŁU BADAWCZEGO PROJEKTU ORAZ PROBLEMY SZCZEGÓŁOWE}

Projekt jest tzw. naturalnym eksperymentem, którego dwie fale zostały przeprowadzone w 2015 i 2017 roku, a więc tuż po wyborach samorzadowych 2014 roku oraz po dwuletnich doświadczeniach funkcjonowania nowej (i starej) ordynacji wyborczej w kilkunastu podobnych polskich miastach. Wyborcy i radni miast, w których wprowadzono większościową ordynacje wyborczą stanowia grupę eksperymentalna, a w miastach, w których ordynacji nie zmieniono - grupe kontrolną. Oczekujemy, że zmiany będą coraz bardziej widoczne wraz $z$ upływającym czasem. 
Najważniejszym celem prezentowanej analizy jest znalezienie odpowiedzi na pytanie, czy w okręgach wyborczych, w których wprowadzono większościowa ordynację wyborczą JOW, odnotowujemy wraz $z$ upływem czasu - większe poczucie politycznego sprawstwa niż w okręgach, gdzie nie dokonano zmiany ordynacji. W badaniu mieliśmy 16 miast podzielonych równo na dwie części na podstawie obowiązujących $\mathrm{w}$ nich dwóch typów ordynacji, $\mathrm{z}$ zachowaniem możliwie najwyższego podobieństwa reszty cech tych miejscowości ${ }^{1}$. W każdym mieście przebadano 100 respondentów, mieszkańców tych miast, co oznacza, że w pierwszej grupie miast (o statusie 'powiatu') zbadaliśmy 800 osób, a w drugiej grupie miast (statusu takiego nie posiadających - także 800 respondentów. W kwestionariuszu wywiadu zamieszczono dwa pytania wskaźnikowe dla 'poczucia politycznego sprawstwa'. Pierwsze brzmiało: „Niektórzy mówią, że to, na kogo się głosuje w wyborach, i tak niczego nie zmieni. Inni mówią, że to, na kogo się głosuje, może wiele zmienić. Używając skali na karcie (gdzie '1' oznacza, że to, na kogo się głosuje i tak niczego nie zmieni, a '5' oznacza, że to, na kogo się głosuje, może wiele zmienić), prosimy zaznaczyć, jak określił(a)by Pan(i) swoje stanowisko...?” Drugie zaś brzmiało: „Zdarza się, że o wyniku wyborów w okręgu decyduja pojedyncze głosy. Jakie Pana(i) zdaniem są szanse, że Pana(i) głos może mieć znaczący wpływ na ostateczny wynik wyborów? (5-stopniowa skala odpowiedzi od ' 1 ' - żadne, po '5' - bardzo duże)". Następnie $z$ obydwu zmiennych utworzono prosty kumulatywny indeks 'poczucia politycznego sprawstwa'. W artykule tym jako zmiennej zależnej używamy tylko tak skonstruowanego indeksu, choć dla innych potrzeb i w innym kontekście obydwie zmienne można traktować jako wskaźniki nieco odmiennych aspektów omawianego zjawiska. Nie jest to jednak przedmiotem niniejszych analiz.

\footnotetext{
Doboru tego dokonano na podstawie techniki zwanej propensity score matching [PSM] (Rubin 2006). W pierwszym etapie przygotowano operat losowania, tzn. zbiór miast podobnej wielkości, wśród których największe liczyło ponad 75 tysięcy mieszkańców, a najmniejsze -38 tysięcy. W kolejnym kroku określono zestaw cech tych miast, pod względem których miały być do siebie podobne. Tak więc, $z$ jednej strony owe cechy były 'predyktorami' faktu, iż miasto ma status 'na prawach powiatu', a $z$ drugiej - cechy mogace mieć wpływ na jakość lokalnej demokracji. Następnie zastosowano model regresji logistycznej, za pomoca którego oszacowano model prawdopodobieństwa posiadania przezeń statusu 'miasta na prawach powiatu', co pozwoliło nam empirycznie wyróżnić takie właśnie miasta oraz miasta, które takiego statusu nie posiadały. W ostatnim kroku dobrano osiem par miast $\mathrm{z}$ jednej strony do siebie najbardziej podobnych (wg $11 \mathrm{cech}$ ), a $\mathrm{z}$ drugiej posiadających odmienny status 'powiatowy'.
} 
W pierwszej części tekstu prezentujemy analizy tłumaczace samo zjawisko poczucia politycznego sprawstwa, a konkretnie - jego determinant zarówno klasycznych strukturalnych (wg cech społeczno-demograficznych, takich jak wiek, wykształcenie itp.), jak i innych społecznych, takich jak: poziom zaufania, stopień zakorzenienia społecznego jednostki oraz jej kapitał społeczny.

W drugiej staramy się odpowiedzieć na pytanie, do jakich skutków politycznych prowadzi wyższy poziom poczucia sprawstwa. Analizujemy zwłaszcza wpływ na partycypację wyborcza, na głosowanie na konkretne partie, na poziom reprezentacji politycznej, na zakres udziału w życiu publicznym oraz na wybrane zagadnienia funkcjonowania władzy lokalnej. Badamy te kwestie statycznie i dynamicznie; $\mathrm{w}$ tym drugim przypadku chodzi rzecz jasna o różnice w wynikach pomiędzy pierwszym a drugim pomiarem naszego badania.

\section{WYNIKI ANALIZ}

W tej części prezentujemy wyniki naszych dociekań. Sa one podzielone na trzy części, odpowiadające trzem analizowanym zmiennym zależnym. W pierwszej mamy do czynienia ze zmienna ciagła oceniająca poziom poczucia politycznego sprawstwa Polaków, skonstruowana za pomoca dwóch zmiennych opisanych powyżej; ogólnie wskazują one na zakres, w jakim jednostka deklaruje posiadanie wpływu na rzeczywistość polityczna kraju. W drugiej mamy do czynienia $z$ zero-jedynkową zmienną zależną wskazująca, czy jednostka brała udział w wyborach lokalnych 2014 roku czy też nie. Trzecia zmienna zależna mierzy ogólny poziom partycypacji wyborczej ludzi na podstawie pytań o uczestnictwo w trzech ostatnich wyborach (w pierwszej fali pytaliśmy o zamiar udziału w wyborach parlamentarnych 2015 roku).

W każdej z trzech analiz wyjaśniajace modele sa podobne. W analizie przedstawionej w tabeli 1 , rozpoczynamy od modelu \#1, w którym zmienna wyjaśniająca jest tylko typ ordynacji wyborczej. W modelu \#2 dodajemy podstawowe zmienne społeczno-demograficzne, w modelach \#3-6 analizujemy niezależny wpływ kilku zmiennych niezależnych, kontrolując jednocześnie inferencję na nie ordynacji wyborczej i zmiennych społeczno-demograficznych. W modelu \#3 analizie poddany jest wpływ zaufania do ludzi, w modelu \#4 - rodzinne (międzypokoleniowe) zakorzenienie jednostki w miejscu zamieszkania, w mo- 
delu \#5 - subiektywne poczucie przywiązania do miejsca zamieszkania, w modelu \#6 - kapitał społeczny jednostki. Model \#7 zawiera $\mathrm{w}$ zbiorze zmiennych niezależnych wszystkie zmienne występujące w modelach 2-6 oraz - dodatkowo - interakcje systemu wyborczego $\mathrm{z}$ nimi. $\mathrm{W}$ końcu, w modelu \#8 analizujemy całość potencjalnych wpływów, dodając trzykierunkowe interakcje: systemu wyborczego, czasu pomiaru (fali badania) oraz zestawu wcześniej opisanych zmiennych, a także dodajemy tu jako zmienna niezależna poczucie politycznego sprawstwa.

Dla dwóch pozostałych zmiennych zależnych dotyczących konkretnej i ogólnej partycypacji wyborczej (tabela 2 i 3), zestaw modeli zmiennych niezależnych jest identyczny jak w wyżej opisanym modelu zaprezentowanym $\mathrm{w}$ tabeli 1 .

\section{DETERMINANTY POCZUCIA SPRAWSTWA POLITYCZNEGO}

Skoro tak niewiele wiemy o poczuciu politycznego sprawstwa w kontekście wyborów lokalnych, najpierw staramy się znaleźć odpowiedź na pytanie o determinanty tego zjawiska. $Z$ wielorakich analiz szczegółowych - dwu- i wieloczynnikowych - prezentujemy tylko kilka ostatecznych kroków regresji wielorakiej wraz z interakcjami. Szukamy bowiem odpowiedzi nie tyle na pytanie, co determinuje owo polityczne sprawstwo, ile staramy się wyjaśnić, zarówno jak czynniki społeczne tłumacza poczucie sprawstwa, niejako same w sobie, jak i co się dzieje, gdy badamy je w odmiennym instytucjonalnym kontekście (ordynacji JOW i proporcjonalnej), uwzględniając jednocześnie wpływ czasu, traktowanego tu jako wpływ socjalizacyjny danej ordynacji wyborczej. Inaczej mówiąc, staramy się odpowiedzieć na pytanie, jak zmienne społeczno-demograficzne i społeczne wpływaja na poczucie sprawstwa, w obydwu kontekstach, gdy kontekst ten jest nowy i bardziej zapoznany (po dwóch latach).

Szczegółowe dane sa przedstawione $\mathrm{w}$ tabeli 1 , jest ich wiele i wpływ każdego zasługuje na oddzielne omówienie, ale w niniejszym opracowaniu staramy się opisać i zrozumieć ogólny obraz zależności. W rzeczywistości tabela 1 przedstawia niejako osiem równań regresji wielorakich, logicznie ze soba powiązanych. 


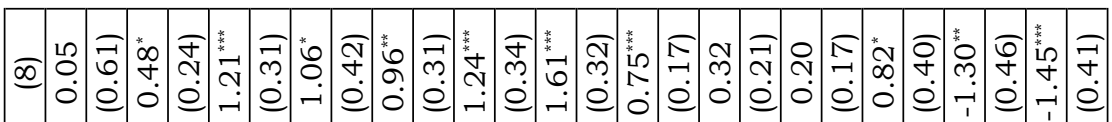

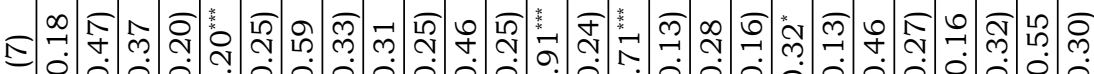

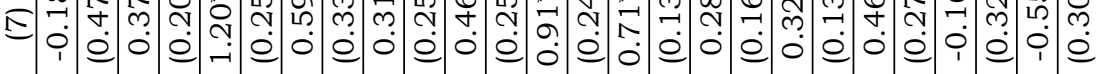

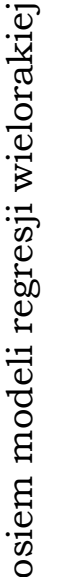

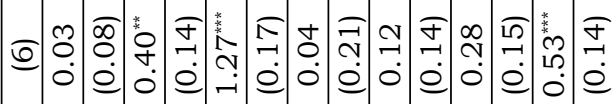
$\begin{array}{lll}* & 0 \\ 0 & \infty & 0 \\ 0 & 0 \\ 0 & 0\end{array}$

ए人)

ص)

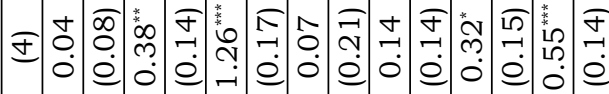

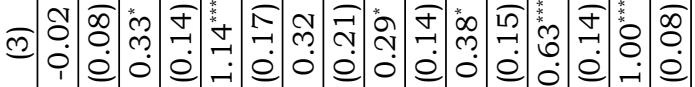

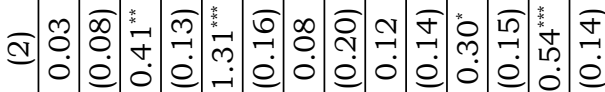

空

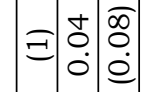

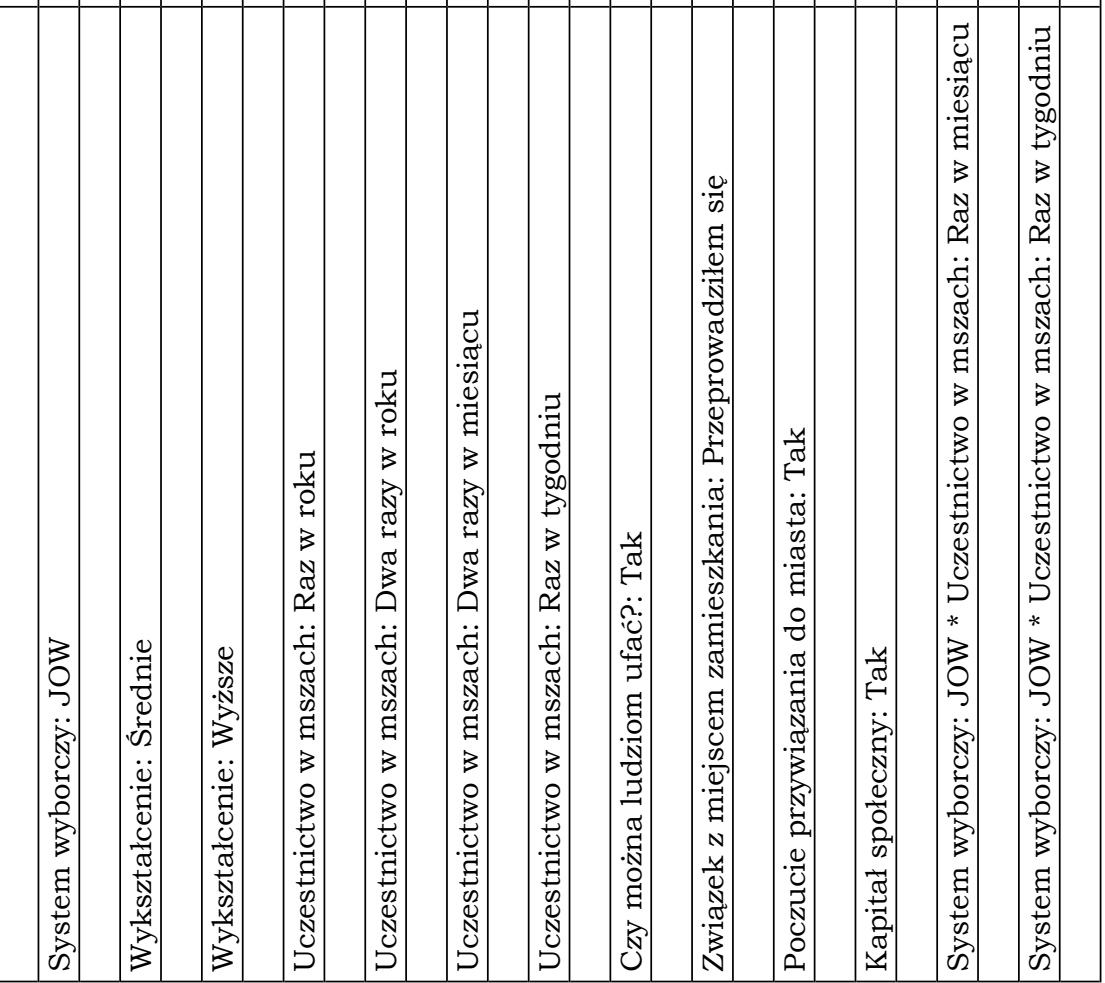




\begin{tabular}{|c|c|c|c|c|c|c|c|c|c|c|c|c|c|c|c|c|c|c|c|c|}
\hline \begin{tabular}{l}
\multirow{2}{*}{} \\
$i$ \\
$i$ \\
$i$ \\
$i$
\end{tabular} & 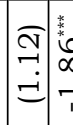 & 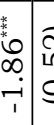 & 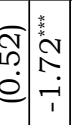 & 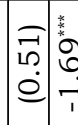 & \begin{tabular}{lll}
6 & 0 \\
0 & 0 \\
0 & 0 \\
\hdashline & 0 \\
\end{tabular} & $\begin{array}{l}\text { ì } \\
\stackrel{*}{*}\end{array}$ & 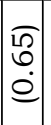 & $\begin{array}{l}\stackrel{3}{*} \\
\stackrel{i}{c} \\
c\end{array}$ & $\mid \begin{array}{l}10 \\
0 \\
0 \\
0\end{array}$ & $\begin{array}{l}\text { ì } \\
\text { ì }\end{array}$ & $\begin{array}{l}\overparen{T} \\
\underline{0} \\
\dot{0}\end{array}$ & $\begin{array}{l}\stackrel{m}{\wedge} \\
\stackrel{c}{c}\end{array}$ & 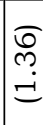 & $\begin{array}{l}\text { ŏ } \\
\text { ó }\end{array}$ & $\left|\begin{array}{l}\mathbb{T} \\
\dot{f} \\
\dot{\theta}\end{array}\right|$ & مै & $\begin{array}{l}\text { o) } \\
\dot{+} \\
\dot{0}\end{array}$ & $\begin{array}{l}10 \\
-1 \\
0\end{array}$ & 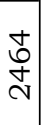 & 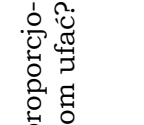 \\
\hline $\begin{array}{l}\text { oे } \\
\dot{-1}\end{array}$ & $\begin{array}{l}0 \\
0 \\
0 \\
0\end{array}$ & & & & & & & & & & & & & & & & $\begin{array}{l}\tilde{m} \\
m \\
0 \\
0\end{array}$ & $\stackrel{N}{\stackrel{1}{0}}$ & 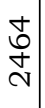 & 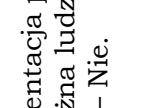 \\
\hline & & & & & & & & & & & & & & & & & 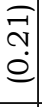 & $\begin{array}{l}1 \\
0 \\
0\end{array}$ & $\begin{array}{c}\circ \\
\stackrel{-}{N} \\
\text { N }\end{array}$ & 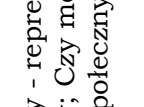 \\
\hline & & & & & & & & & & & & & & & & & 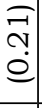 & 今. & $\begin{array}{l}\stackrel{+}{N} \\
\stackrel{N}{N}\end{array}$ & 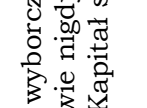 \\
\hline & & & & & & & & & & & & & & & & $\begin{array}{l}\text { 裳 } \\
\text { in } \\
\text { in }\end{array}$ & $\begin{array}{l}\overparen{N} \\
\text { Na} \\
\stackrel{0}{0}\end{array}$ & ? & 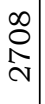 & 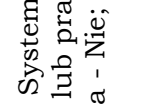 \\
\hline & & & & & & & & & & & & & & & & बे & $\begin{array}{l}\overparen{\mathfrak{N}} \\
\text { a } \\
0\end{array}$ & 음 & 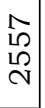 & 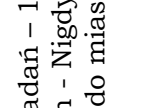 \\
\hline & & & & & & & & & & & & & & & & $\begin{array}{l}\text { w } \\
0 \\
1 \\
10 \\
10\end{array}$ & 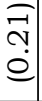 & $\begin{array}{l}10 \\
0 \\
0\end{array}$ & $\begin{array}{l}0 \\
\stackrel{1}{1} \\
\stackrel{2}{N}\end{array}$ & 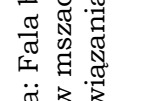 \\
\hline & & & & & & & & & & & & & & & & $\begin{array}{l}\infty \\
1 ? \\
0 \\
0\end{array}$ & $\begin{array}{l}0 \\
0 \\
0 \\
0\end{array}$ & 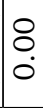 & $\begin{array}{l}-1 \\
\bar{\sigma} \\
\text { ลे }\end{array}$ & 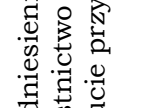 \\
\hline 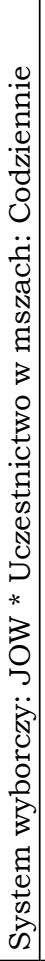 & & 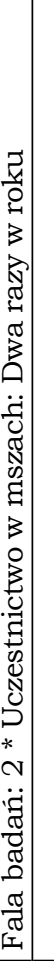 & 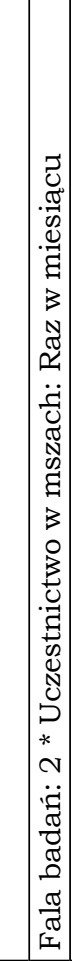 & 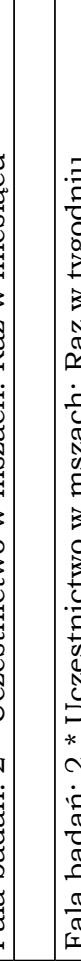 & 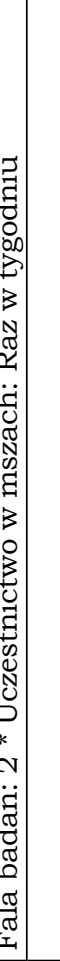 & 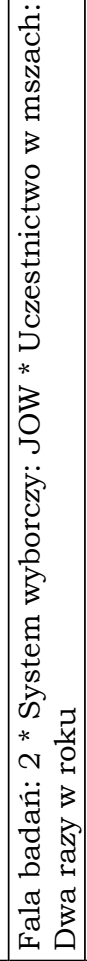 & & 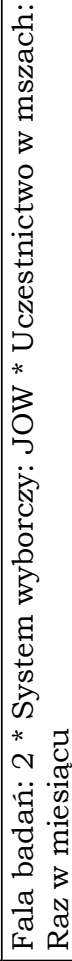 & & 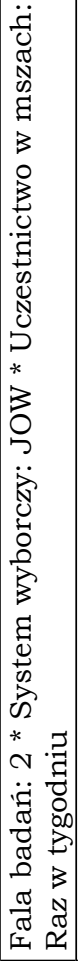 & & 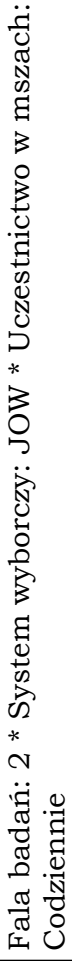 & & 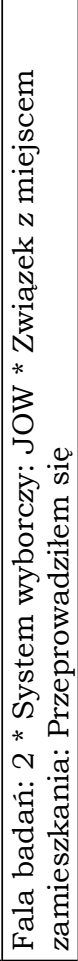 & & 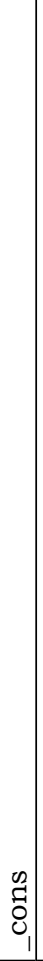 & & ָ & Z & 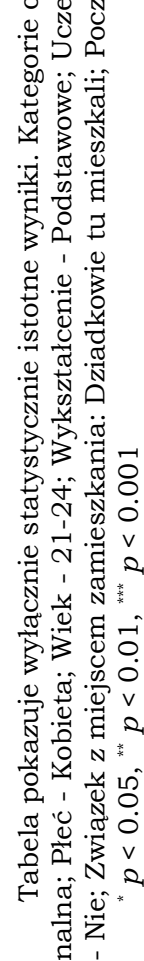 \\
\hline
\end{tabular}


Skupmy się na najważniejszych wynikach. I tak, po pierwsze, poziom wykształcenia badanych jest silnie i statystycznie istotnie związany $z$ poziomem poczucia sprawstwa politycznego: osoby $z$ wykształceniem podstawowym wykazuja znacznie niższe poczucie sprawstwa niż osoby $z$ wykształceniem średnim i wyższym. Po drugie, osoby uczęszczające do kościoła raz w tygodniu maja wyższe poczucie sprawstwa niż ci, którzy nigdy w kościele w ogóle nie bywaja, ale także wyższe niż bywajacy w nim codziennie. Po trzecie, pozostałe klasyczne zmienne społeczno-demograficzne (płeć, wiek) nie wpływaja na poziom poczucia politycznego sprawstwa. Po czwarte, silnie i istotnie statystycznie wpływają na poczucie politycznego sprawstwa czynniki opisujacce społeczną sytuacje badanych, a więc wyższy poziom owego sprawstwa odnotowujemy wśród osób ufającym innym, niż wśród cechujących się brakiem zaufania do bliźnich; wśród osób zwiazanych silniej ze swym miejscem zamieszkania niż wśród osób o luźniejszych z nim związkach; wykazujących wyższy kapitał społeczny, niż niższy. Po piąte, i w koń$\mathrm{cu}$, nie odnotowujemy statystycznie istotnych różnić w naszych dwóch typach kontekstu instytucjonalnego - w jednomandatowych okręgach wyborczych i w tych, gdzie stosowana jest ordynacja proporcjonalna.

Teoria politologiczna nie watpi w silny pozytywny związek poczucia politycznego sprawstwa $z$ partycypacja wyborcza. Dlatego analizie poddaliśmy przyczyny partycypacji wyborczej badanych zarówno w konkretnych wyborach lokalnych 2014 roku, jak i w trzech ostatnich wyborach lat 2014-2015. W tabeli 2 prezentujemy determinanty uczestnictwa w wyborach lokalnych 2014 roku.

Uzyskane wyniki pozwalają na następujące uogólniające uwagi. Po pierwsze, osoby zamieszkujące w miejscowościach JOW głosowały rzadziej niż zamieszkujące w miastach PR. Po drugie, poczucie sprawstwa jest silnym czynnikiem wpływającym na partycypację wyborczą. Po trzecie, mężczyźni częściej biorą udział w wyborach niż kobiety. Po czwarte, osoby najmłodsze, w wieku do 24 lat, głosuja najrzadziej. Po piąte, wykształcenie silnie i statystycznie istotnie wpływa na partycypację wyborczą, im wyższe tym większe prawdopodobieństwo udziału w wyborach.

Zarysowany wyżej obraz nie odbiega od tego, który odnotowujemy $\mathrm{w}$ badaniach na poziomie ogólnonarodowym. Dodajmy, przedstawione rezultaty wpływu poszczególnych czynników na poczucie sprawstwa i na partycypację wyborczą są czystym wpływem 'netto', po kontroli wpływu innych czynników.

W tabeli 3 przedstawiamy podobne dane lecz dotyczące ogólnej partycypacji wyborczej Polaków w latach 2014-2015. 
ब.

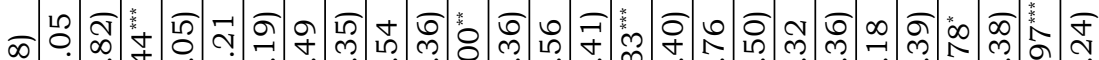

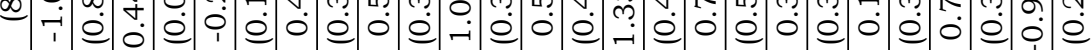

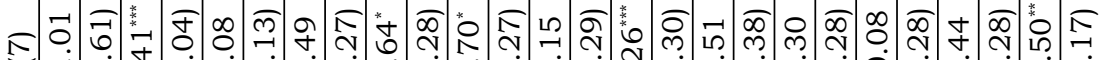

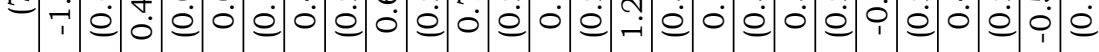

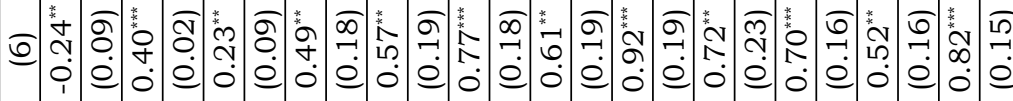

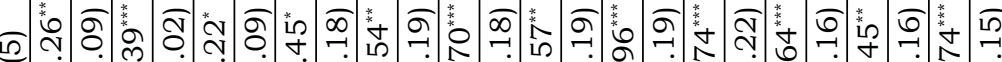

ص)

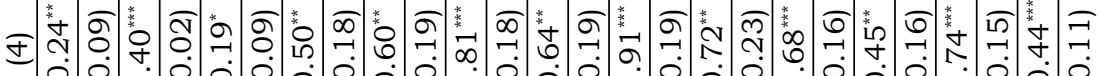

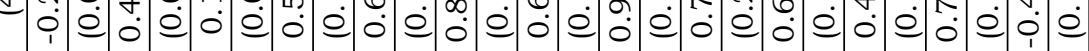

C

인

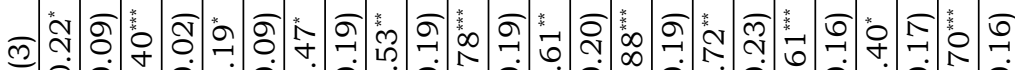

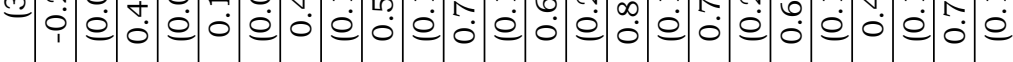

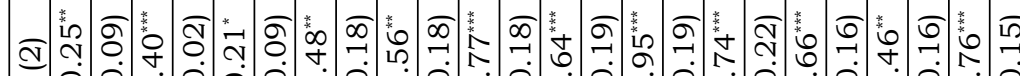

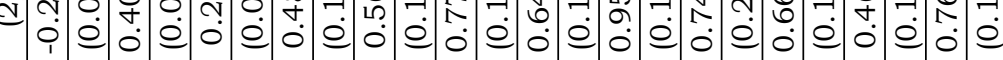

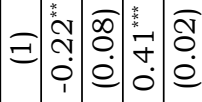




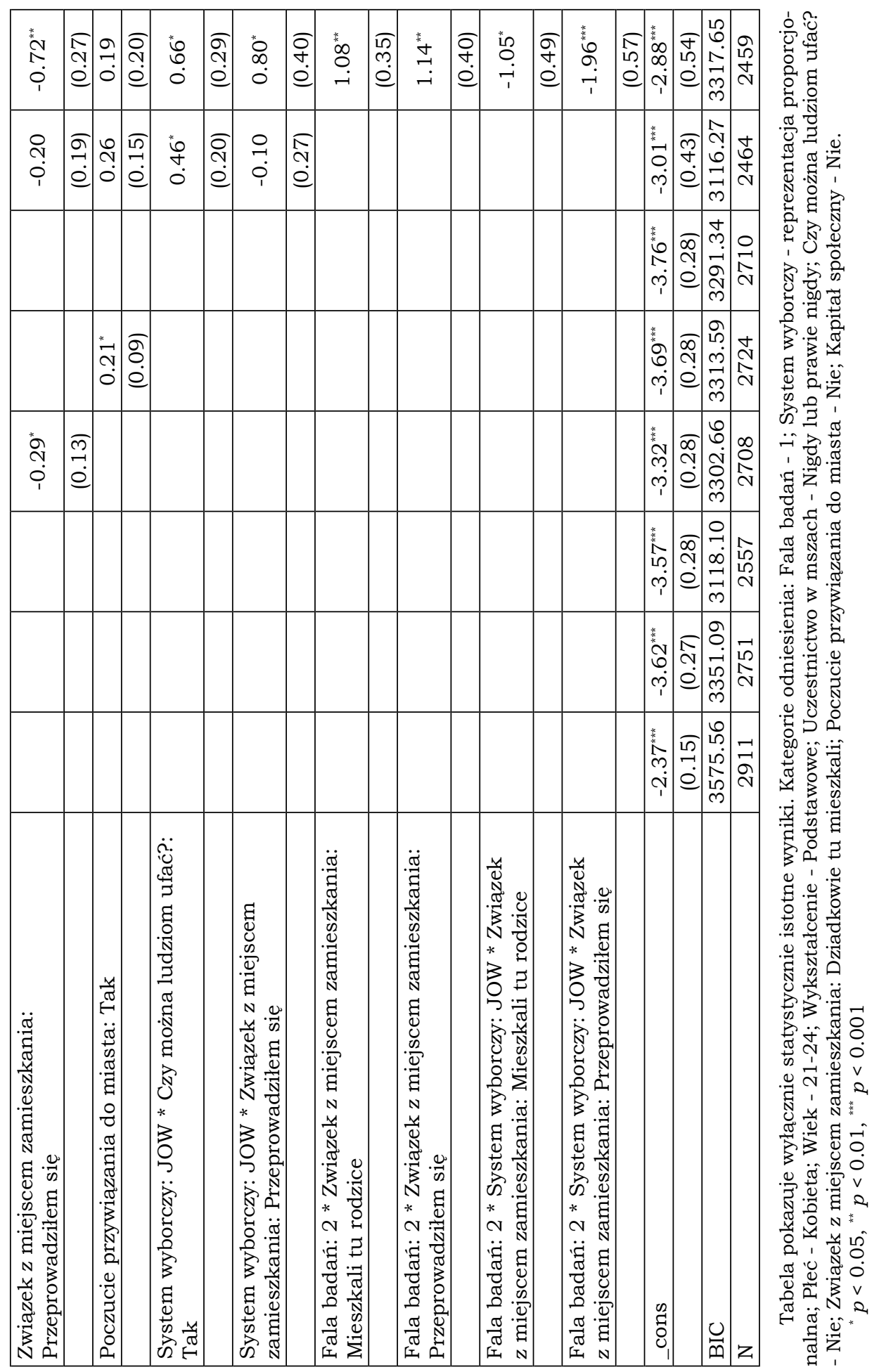




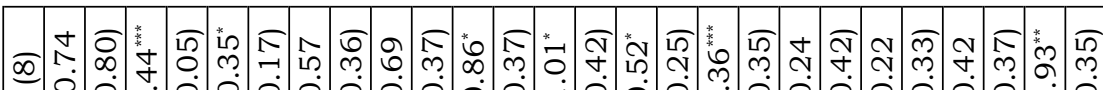

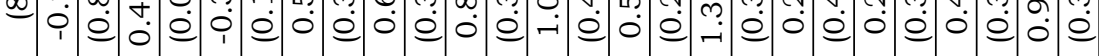

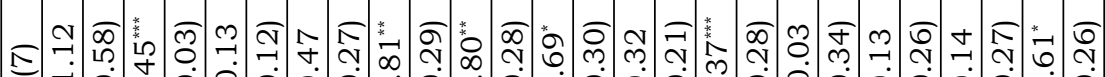

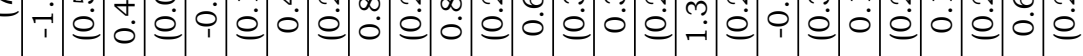

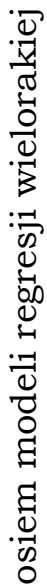

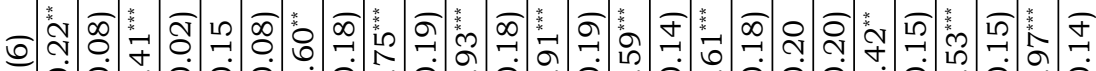

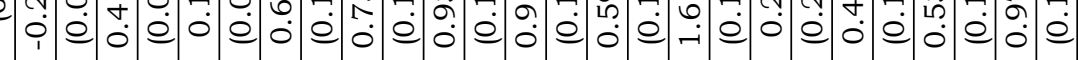

ส

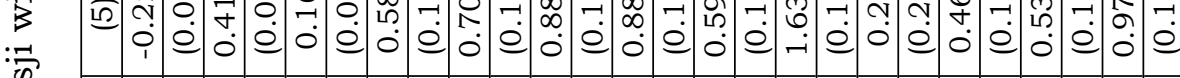

ช

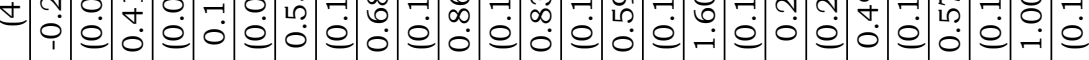

ल ণิ宀

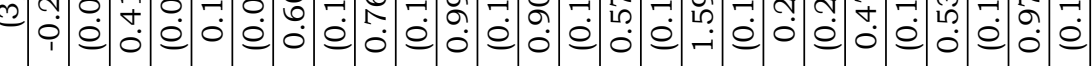

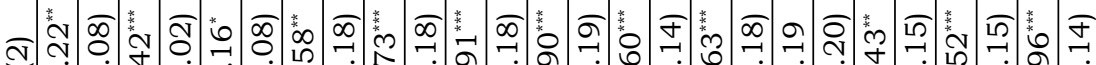

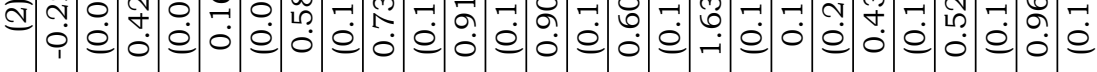

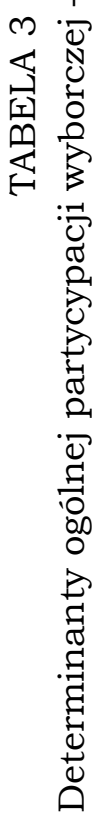

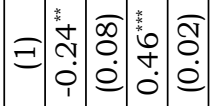




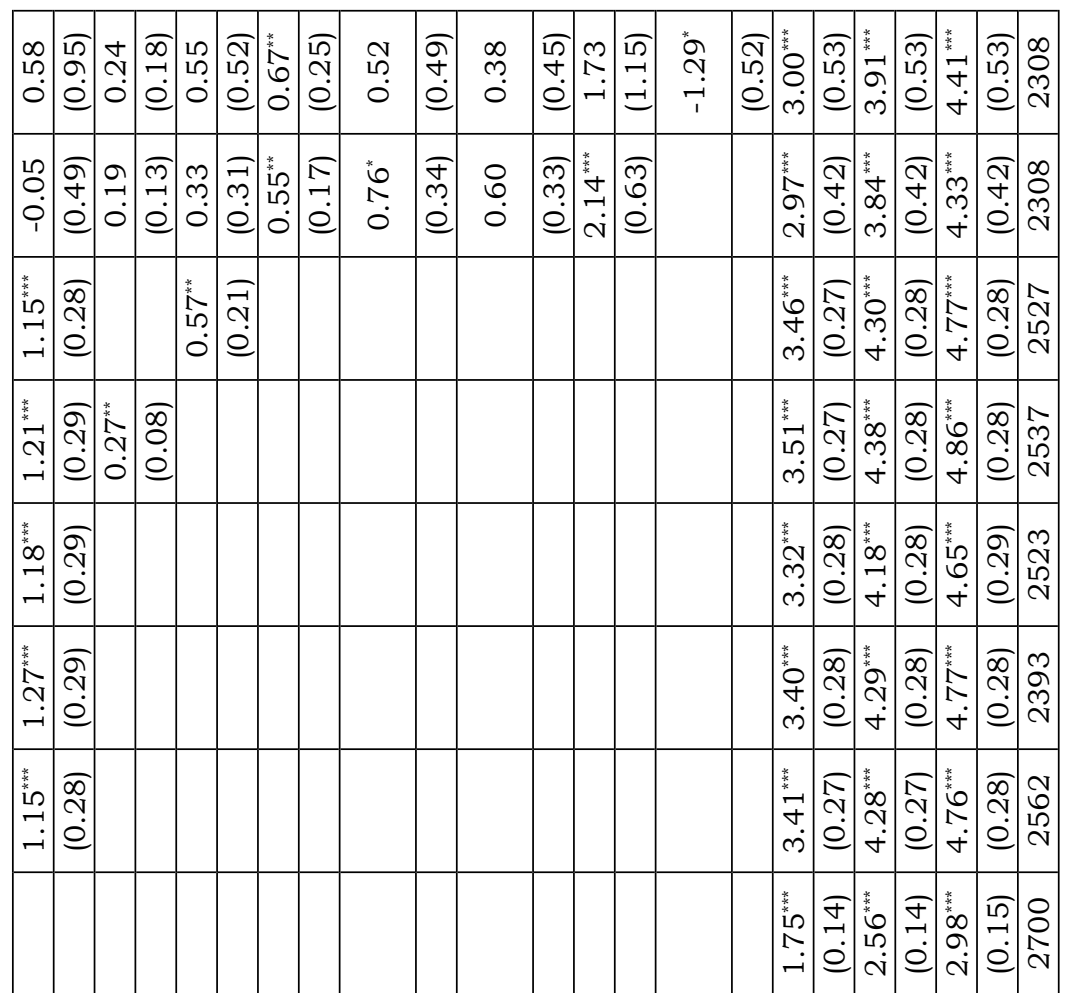

高囦

믄.

.$\frac{\pi}{2}$

急 灵

N

过惢

度穷

욤

s.

द्व

告抎

.

设

.

흉 ల్ల

. है है

$\infty_{0} 3 \cdot 3$

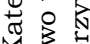

들

1 更

त్ ญ్ ญ

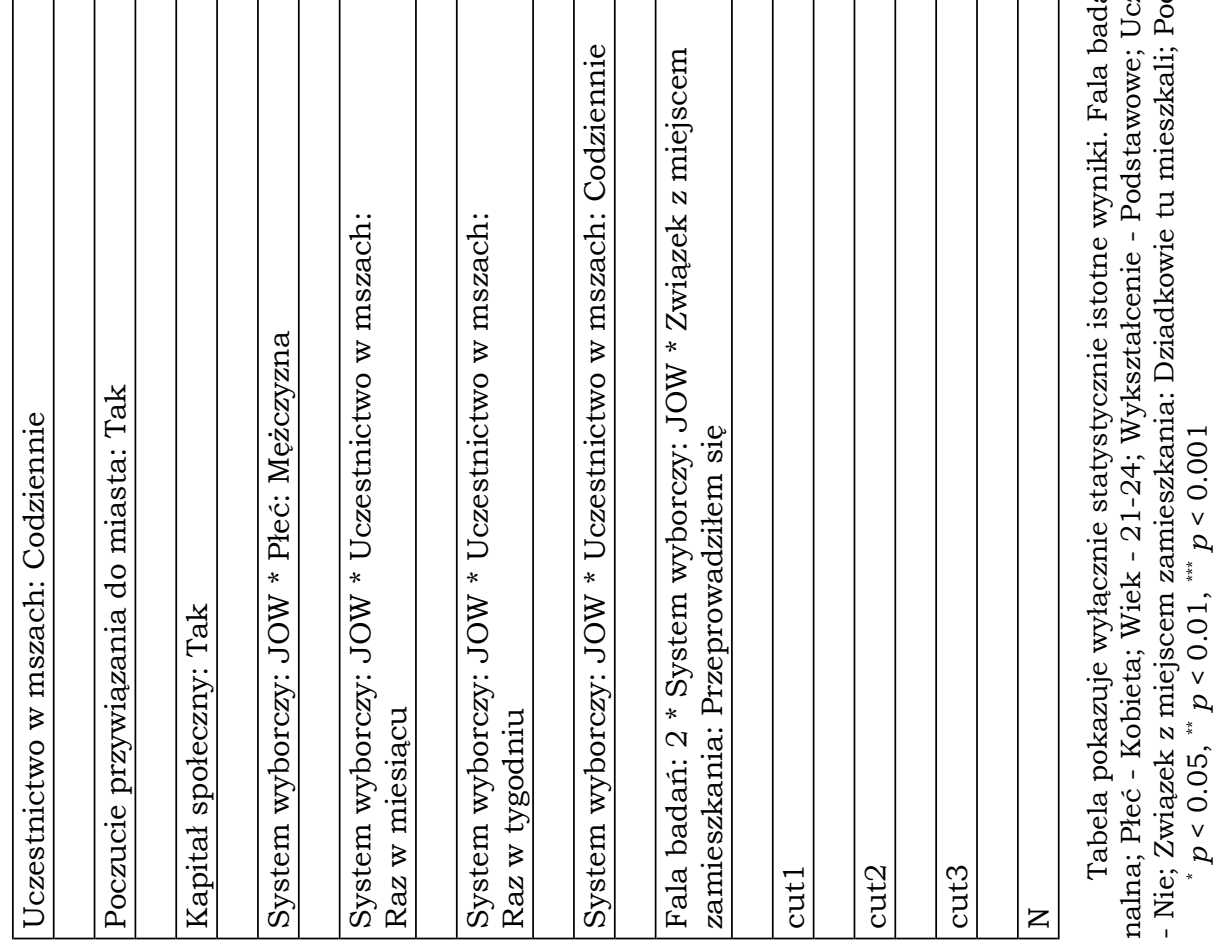


Nie wnikając w szczegóły danych tabeli 3 zauważmy jedynie, iż są one niemal tożsame $z$ wynikami przedstawionymi $\mathrm{w}$ tabeli 2 . Oznacza to, że determinanty partycypacji wyborczej w wyborach lokalnych niewiele różnią się od ogólnych determinant uczestnictwa wyborczego. Można jedynie odnotować trzy różnice. Wśród determinant ogólnej partycypacji (tabela 3) statystycznie istotny wpływ okazuja: kapitał społeczny, bycie mężczyzną oraz mniejsze znaczenie słabego przywiązania do obrzędów religijnych.

Przechodzimy teraz do szczegółowych wyników, w większości z interakcjami płynącymi $z$ kontekstu instytucjonalnego, $w$ jakim występuja. Zacznijmy od kwestii podstawowych. Jaki jest średni poziom naszego podstawowego czynnika - poczucia sprawstwa politycznego - w miastach o dwóch różnych ordynacjach wyborczych, w dwóch punktach czasowych, w roku 2015 i 2017. Innymi słowy, interesujemy się tym, jaki jest poziom poczucia sprawstwa oraz czy zmienia się $\mathrm{w}$ czasie - w domyśle - pod wpływem doświadczeń z różnych rozwiązań politycznych.

RYSUNEK 1

Średni poziom poczucia sprawstwa

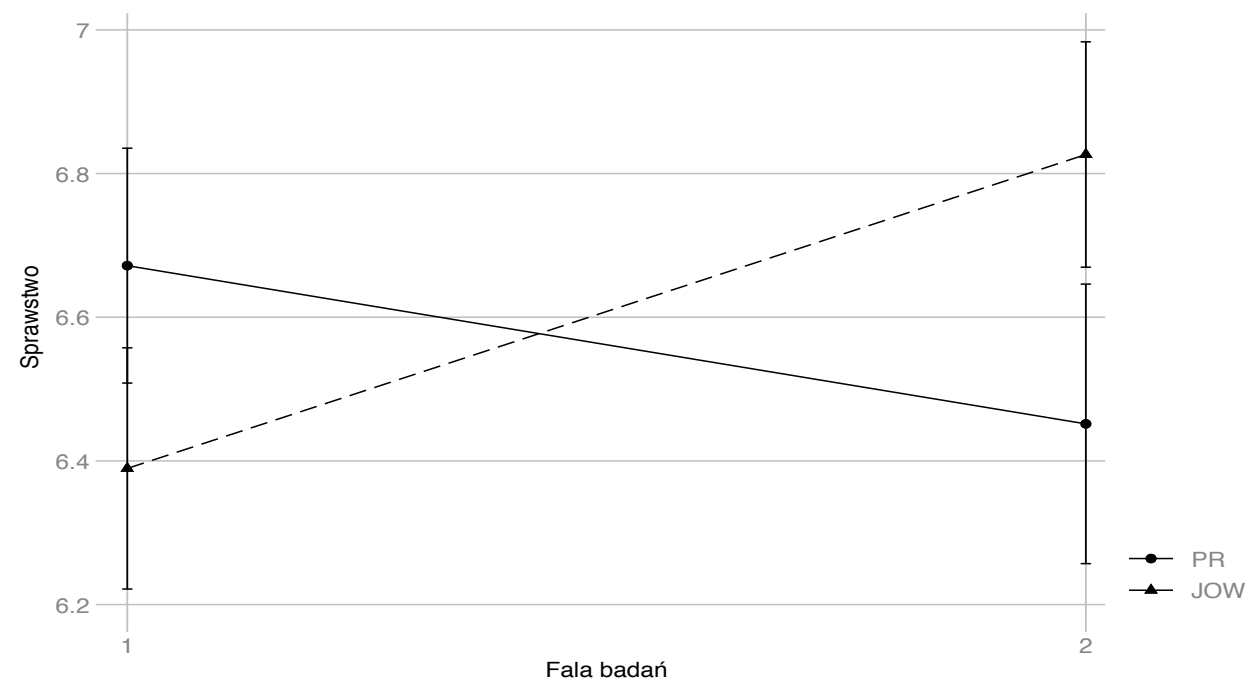

Wyniki naszych analiz, przedstawione na rysunku 1 są dość jednoznaczne - wraz z upływającym czasem poczucie sprawstwa rośnie znacznie w miejscowościach JOW, a maleje, choć mniej wyraziście $\mathrm{w}$ tych, gdzie stosowana jest ordynacja proporcjonalna (PR). 
Nie mniej istotna jest analiza zwiazku poczucia sprawstwa $z$ partycypacja wyborczą zarówno w ostatnich wyborach lokalnych 2014 roku, jak i $z$ ogólnym indeksem partycypacji. Rysunek 2 ukazuje prawdopodobieństwo partycypacji w wyborach 2014 roku w zależności od różnych poziomów poczucia sprawstwa w miastach o dwóch różnych systemach wyborczych.

\section{RYSUNEK 2}

Sprawstwo i partycypacja w wyborach samorzadowych w 2014 roku

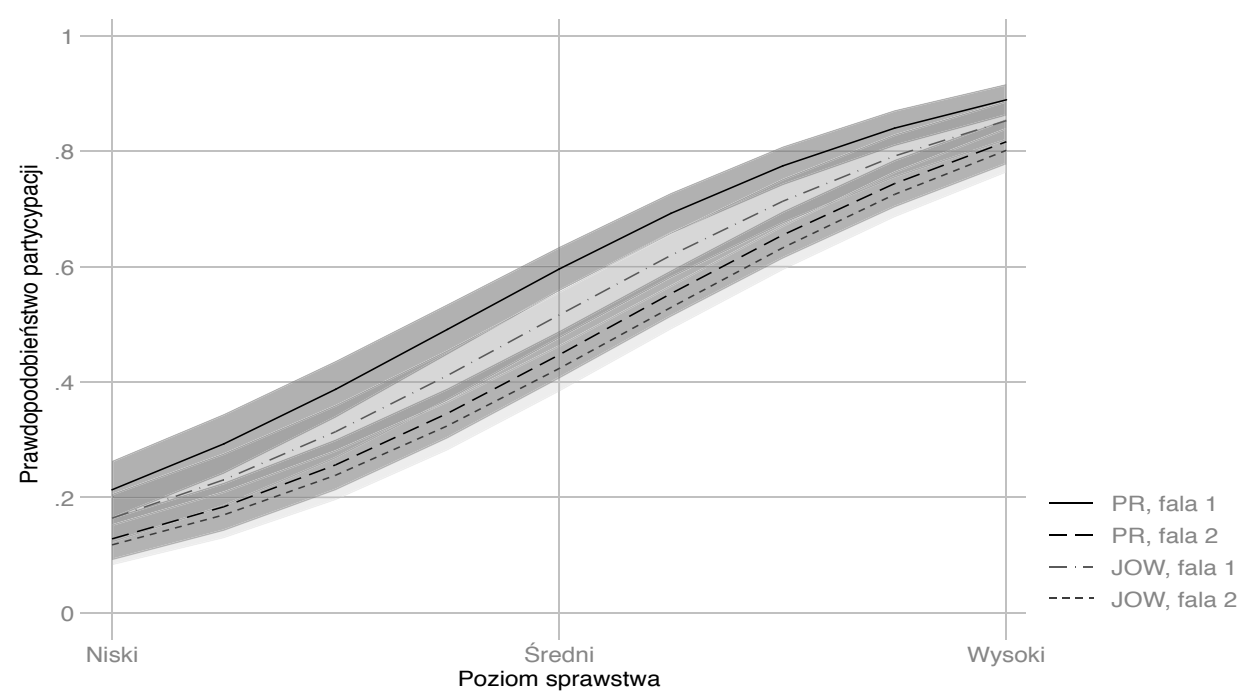

Dane ujawniają silną zależność prawdopodobieństwa udziału w wyborach od poziomu poczucia sprawstwa; zależność ta ma miejsce zarówno $z$ miastach o ordynacjach JOW jak i PR, lecz nie odnotowujemy istotnych różnic w dwóch punktach czasowych, choć w systemach PR w obydwu punktach czasowych zależność ta jest silniejsza.

Oprócz pytania o udział w konkretnych wyborach lokalnych 2014 roku, skonstruowano także ogólny indeks partycypacji wyborczej w oparciu o pytania o uczestnictwo w kilku ostatnich wyborach. Uzyskane wyniki ukazują dość skomplikowane związki z poczuciem politycznego sprawstwa. 


\section{RYSUNEK 3}

Indeks partycypacji w ostatnich wyborach

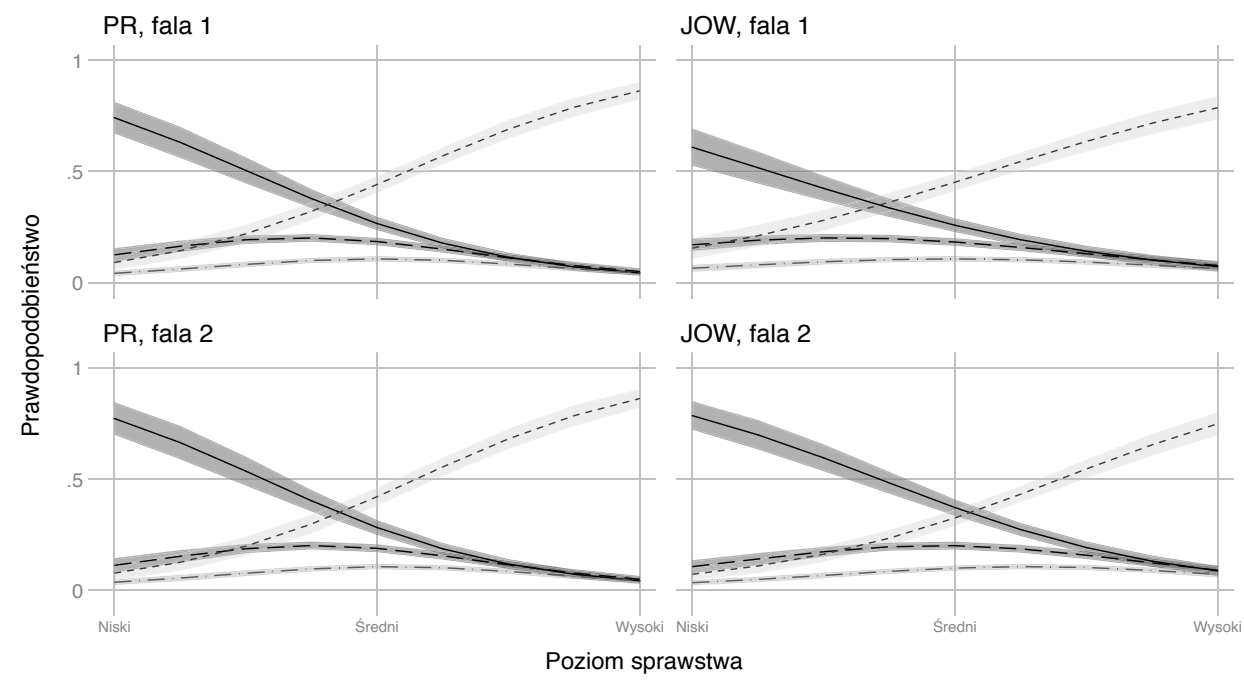

Uogólniając rozkłady ukazane na rysunku 3, można powiedzieć, że różnią się - pod interesującym nas tutaj względem - osoby w ogóle nie biorace udziału w żadnych wyborach oraz osoby uczestniczace we wszystkich. Ci pierwsi - niezależnie od ordynacji i czasu pomiaru - wykazuja bardzo wysokie prawdopodobieństwo apatii wyborczej, gdy cechuje ich niskie poczucie sprawstwa, a ci drudzy - charakteryzują się wysokim prawdopodobieństwem udziału, gdy maja wysokie poczucie sprawstwa. Zależność ta jest uniwersalna i właściwie niezależna od naszych dwóch zmiennych kontekstowych, jednak nieco istotniejsza w miastach o systemach PR, niezależnie od fali pomiaru.

\section{POCZUCIE POLITYCZNEGO SPRAWSTWA A KWESTIE LOKALNE}

Przechodzimy teraz do omówienia klasycznych relacji między poczuciem politycznego sprawstwa a szczegółowymi aspektami udziału badanych w społeczności lokalnej, ich zaangażowania w sprawy publiczne i lokalne decyzje polityczne.

Po pierwsze, interesuje nas zagadnienie dla omawianej problematyki dość kluczowe, a mianowicie czy jest tak, że ludzie wybierający swych przedstawicieli w JOW wykazuja się większa ich znajomościa, są lepiej o nich poinformowani, pamiętaja więcej o samych wyborach oraz jak zależność ta jest współdeterminowana stopniem poczucia sprawstwa. Rysunki 4 i 5 ukazują nam zależności między poziomem poczucia sprawstwa a: (1) pamięcia na kogo badany głosował w wybo- 
rach 2014 roku, (2) wiedzą $z$ jakiego komitetu wyborczego startował. W obydwu kwestiach widzimy klarowny pozytywny zwiazek między wyższym poziomem sprawstwa politycznego a wiedzą o tym, na kogo głosowano oraz $z$ jakiego komitetu wyborczego kandydat startował.

\section{RYSUNEK 4}

Czy pamięta Pan(i), na kogo Pan(i) głosował(a) w wyborach do Rady Miasta w 2014 roku?

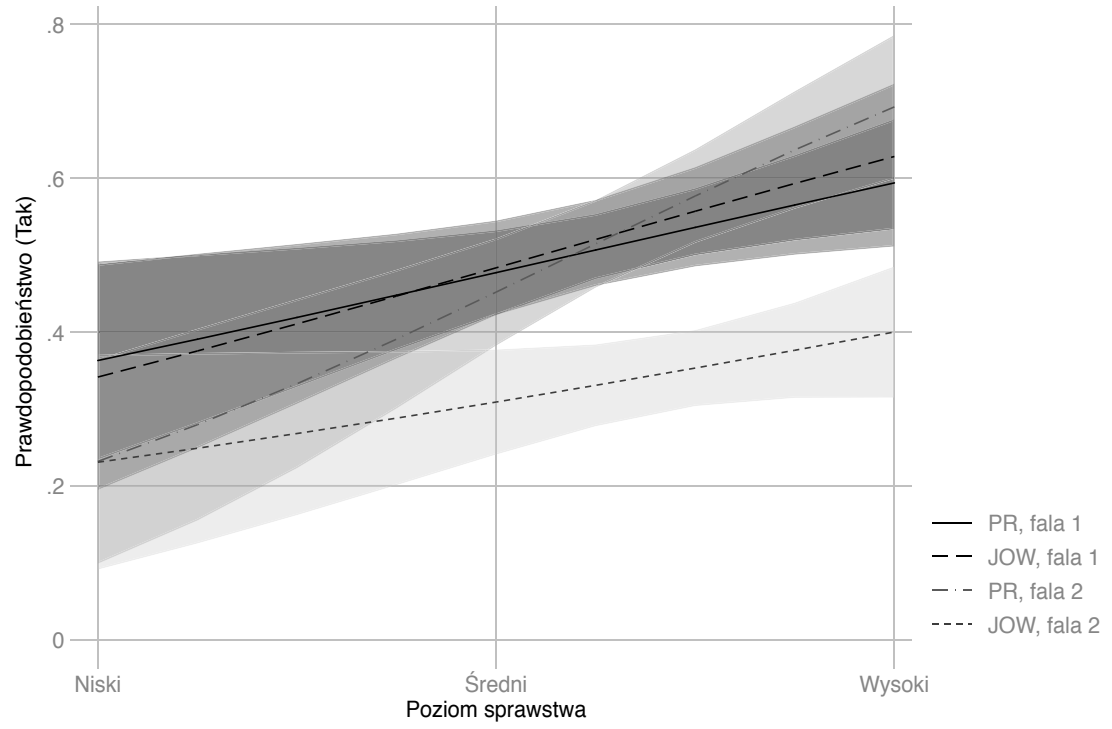

RYSUNEK 5

Czy pamięta Pan(i) $z$ jakiego komitetu wyborczego startował ten/ta kandydat(ka)?

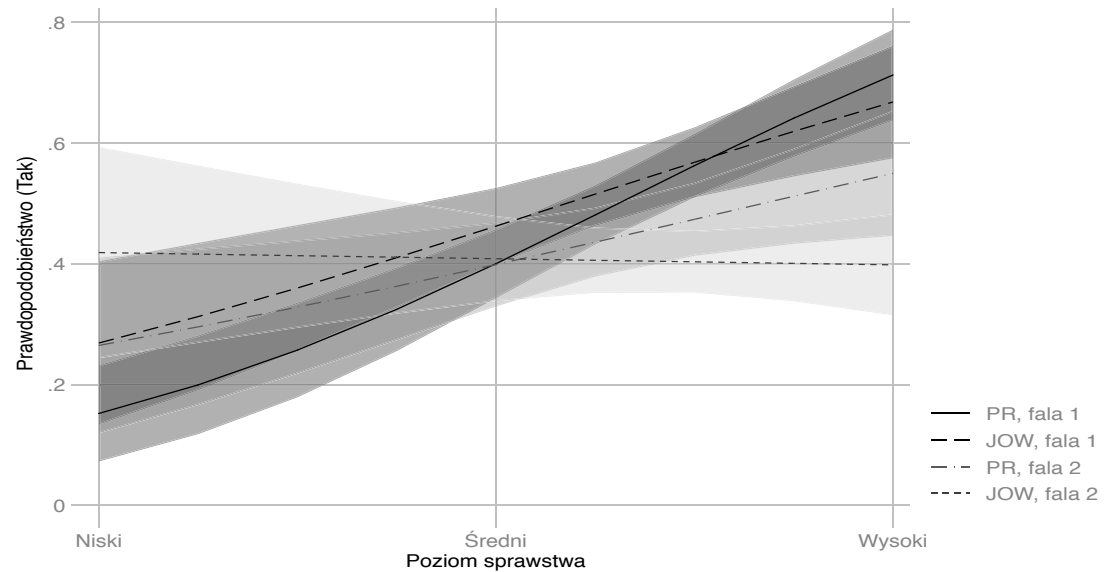


Kilka dodatkowych uwag: (1) Zależność ta jest silniejsza w przypadku wiedzy o komitecie wyborczym, niż gdy dotyczy pamięci o samym kandydacie. (2) Lepsza pamięć - przy takich samych poziomach poczucia sprawstwa - cechuje badanych w okręgach PR - zwłaszcza w II fali badania widoczna jest statystycznie istotna różnica między miejscowościami PR a JOW. (3) Wiedza o komitecie wyborczym kandydata zależy silniej (niż ich lepsza pamięć na kogo głosowali) od poziomu poczucia sprawstwa, zwłaszcza gdy to poczucie jest wysokie oraz gdy dotyczy miejscowości o ordynacji PR. Inaczej mówiąc, dynamika zmiany w zależności od poziomu poczucia sprawstwa jest znacznie silniejsza w miejscowościach PR (w drugiej fali w miejscowościach JOW poziom poczucia sprawstwa w ogóle nie wpływa na tę wiedzę).

SPOEECZNE ZAKORZENIENIE BADANYCH A POCZUCIE POLITYCZNEGO SPRAWSTWA

W teoretycznej refleksji odnoszaccej się do politycznej reprezentacji, jej jakości oraz do poczucia politycznego sprawstwa jednym $z$ kluczowych pytań jest to dotyczace wpływu społecznego zakorzenienia jednostek jako determinanty. W naszym projekcie ów stopień zakorzenienia odtwarzamy za pomoca odpowiedzi na pytanie, od kiedy badany (i jego przodkowie) mieszkaja w danej miejscowości oraz odtwarzając subiektywne poczucie przywiazania do miejscowości. Rysunek 6 ukazuje nam ciekawy obraz tej pierwszej zależności. I tak, najogólniej rzecz ujmując, społeczne zakorzenienia ma słaby zwiazek $z$ poziomem poczucia politycznego sprawstwa. Jest jednak wyjątek: wśród osób, zamieszkujaccych miasta o ordynacji JOW, którzy sami przeprowadzili się do danej miejscowości, w drugim pomiarze odnotowujemy znacznie wyższy poziom poczucia sprawstwa.

RYSUNEK 6

Zwiazek $z$ miejscem zamieszkania i sprawstwo

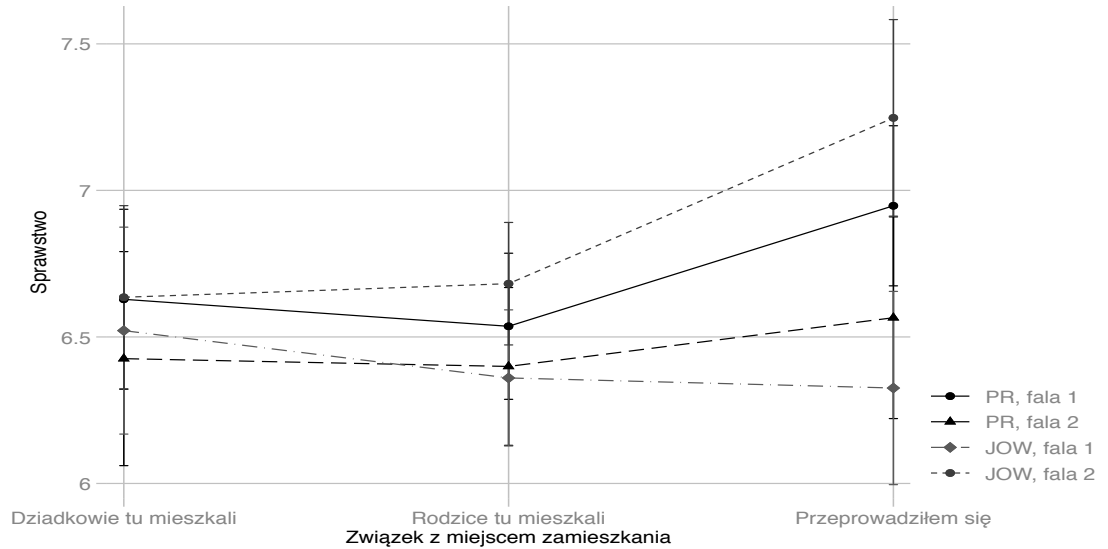


Wynik trudny do jednoznacznej interpretacji, ale można się pokusić o następująca sugestię: osoby mobilne społecznie, słabiej osadzone we wspólnocie lokalnej sa bardziej indywidualistyczne, a JOW, które promuja indywidualnych kandydatów, wydaja się bardziej 'pasować' do takich osób. W naszym przypadku chodzi jednak o coś więcej- wyższe poczucie sprawstwa pojawia się dopiero po pewnym czasie, gdy badani doświadczają działania JOW.

Interesowaliśmy się też subiektywną stroną zagadnienia; tym czy poziom przywiązania badanych do miasta wpływa na poczucie sprawstwa. Ogólny wynik (patrz rysunek 7) mówi nam, że w tym przypadku nie widać statystycznie istotnych relacji między przywiązaniem do miasta a poczuciem sprawstwa, choć jest on dla badanych w obydwu typach miejscowości i w dwu punktach czasowych pozytywny.

\section{RYSUNEK 7}

Poczucie przywiazania do miasta i sprawstwo

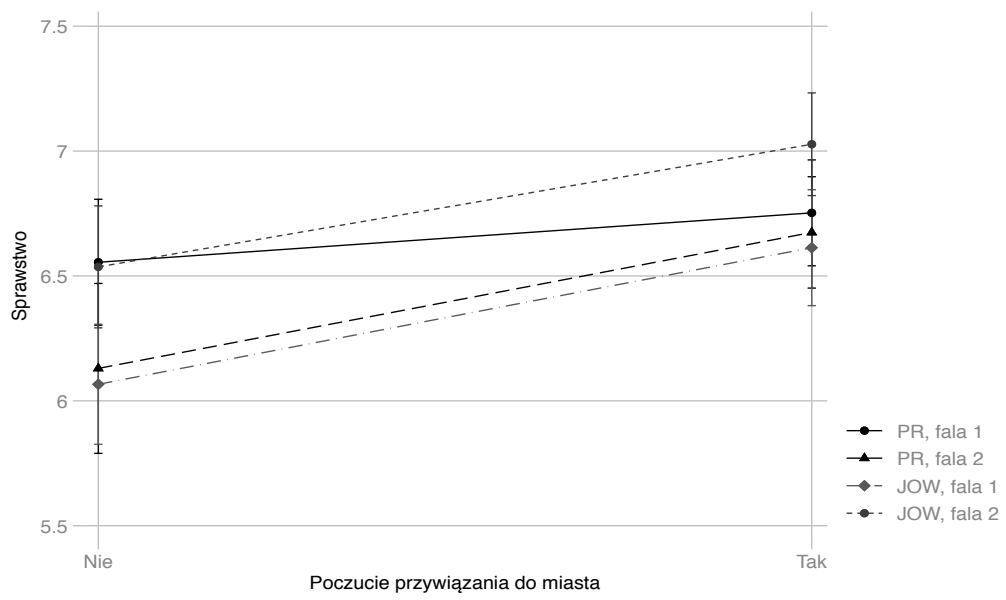

Nie odnotowujemy natomiast różnic w poziomie poczucia sprawstwa wśród osób o różnym poziomie zaufania do innych oraz kapitału społecznego (dane do wglądu), choć jest to spowodowane prawdopodobnie tym, iż takich, którzy aktywnie działaja w organizacjach (co było wskaźnikiem kapitału społecznego), jest niewielu.

WIZJE PRZEDSTAWICIELSTWA POLITYCZNEGO

A POCZUCIE SPRAWSTWA POLITYCZNEGO

Zagadnienia reprezentacji politycznej stanowią osiowy komponent demokracji wyborczej; to różne aspekty poszczególnych teorii reprezentacji najlepiej oddaja istotę skomplikowanych relacji jednostka - 
świat polityki. W naszych badaniach poddaliśmy analizie potoczne wizje roli radnego, po pierwsze, czy jest to wizja delegata realizujacego wolę mieszkańców, czy powiernika realizującego interesy i wartości mieszkańców, ale w sposób, jaki sam uznaje za najlepszy; oraz po drugie, w jakim stopniu chodzi mieszkańcom o reprezentacje 'społeczna' radnych, tj. o to, by byli po prostu do mieszkańców jak najbardziej podobni w sensie społeczno-demograficznym. Wyniki przedstawione sa na rysunkach 8 i 9 .

\section{RYSUNEK 8}

Radny powinien realizować dokładnie to, czego chcą obywatele miasta

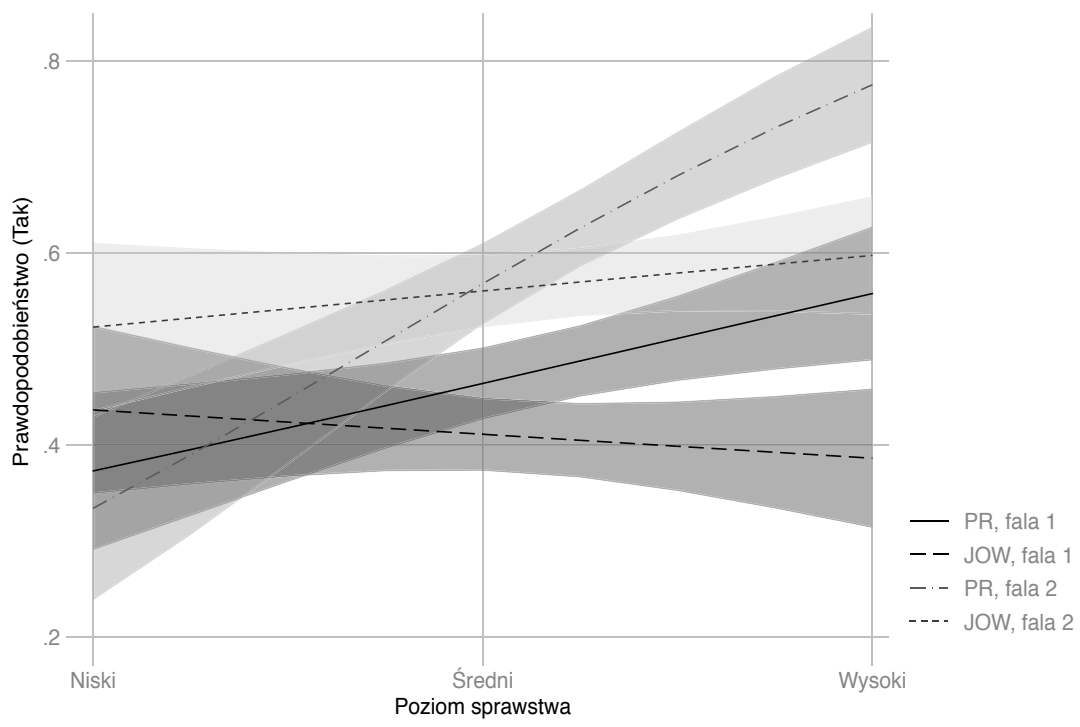

I tak, najważniejszy wynik dotyczy tego, iż tylko w miejscowościach PR widoczna jest - wraz ze wzrostem poziomu poczucia sprawstwa preferencja dla wizji powiernika, który realizuje ich interesy, kierując się swoją wiedza, doświadczeniem i ocena sytuacji. Widoczne jest to już w pierwszej fali, ale znacznie silniej - w drugiej. W miastach JOW nie widać żadnej zależności wizji przedstawicielstwa od poziomu poczucia sprawstwa, choć przy najniższym poczuciu sprawstwa to właśnie $\mathrm{w}$ miejscowościach JOW odnotowujemy wyższe prawdopodobieństwo poparcia tej wizji reprezentacji, jednak różnice sa tu statystycznie nieistotne.

Co się zaś tyczy oczekiwania, by radni byli 'społecznie' podobni do mieszkańców swych miejscowości, analizy nasze wskazują dość logiczny zwiazek z poprzednim wynikiem. 


\section{RYSUNEK 9}

Radni powinni być jak najbardziej podobni do mieszkańców miasta

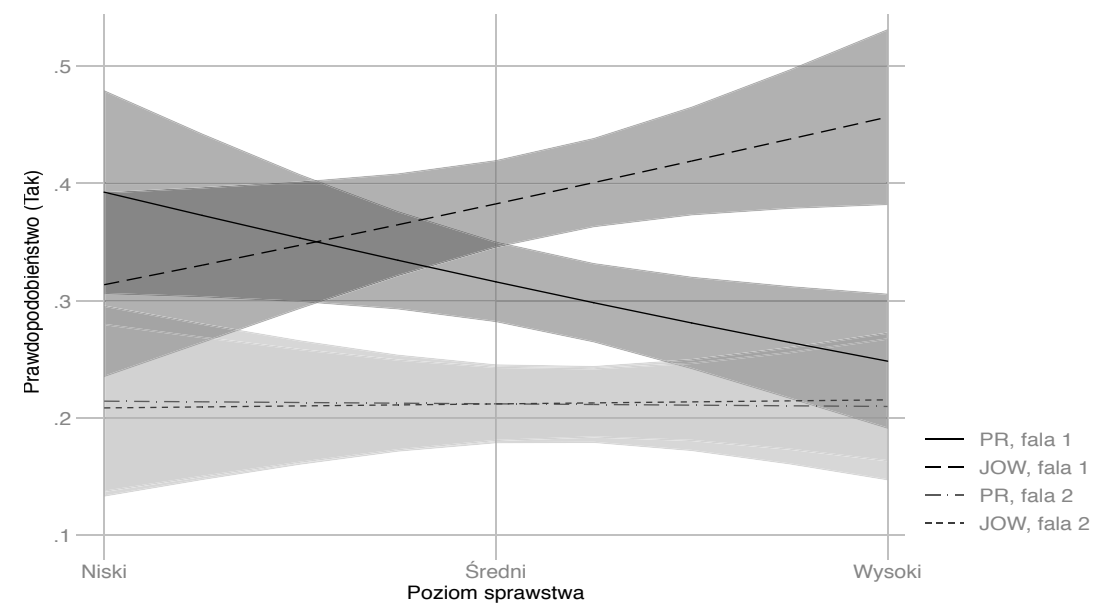

A mianowicie, po pierwsze, w pierwszej fali oczekiwanie to jest generalnie znacznie wyższe; po drugie, oczekiwanie to jest silnie i statystycznie istotnie zależne od poziomu poczucia sprawstwa $\mathrm{w}$ taki sposób, iż wraz ze wzrostem tegoż rośnie to oczekiwanie w miejscowościach JOW, a zarazem wyraźnie maleje w miejscowościach PR. Po trzecie, w drugiej fali nie odnotowujemy takich różnic i co więcej, w obydwu typach miejscowości zależność od stopnia poczucia sprawstwa wygląda identycznie, a jednocześnie jest niższa niż w przypadku pomiaru pierwszej fali.

\section{KONKLUZJE}

1. Przedstawione dane upoważniaja do trzech kluczowych wniosków: poczucie sprawstwa jest w polskich wyborach lokalnych determinowane - w większości - czynnikami, które sugeruje współczesna teoria politologiczna oraz widoczny jest klarowny zestaw czynników warunkujacych partycypację wyborcza, a także - zgodnie $z$ oczekiwaniami - odnotowujemy silny zwiazek między poczuciem sprawstwa politycznego a partycypacja wyborcza.

2. Odpowiedź na nasze najogólniejsze pytanie badawcze jest pozytywna: tak w miejscowościach, w których zaczęto stosować - wraz z upływającym czasem (różnica między I a II fala badań) ordynację większościowa w JOW rośnie poczucie politycznego sprawstwa.

3. Nie sposób przytaczać tu licznych innych interakcyjnych zależności opisanych w tekście, pozwólmy sobie zatem na dwie uogólniające 
uwagi. Po pierwsze, wiele przedstawionych zależności jest skomplikowanych oraz trudnych do interpretacji. Wynika to zapewne częściowo $z$ faktu, iż polski ustawodawca na początku roku 2017 zaczą wycofywać się $z$ proponowanych rozwiąań prawnych, co ostatecznie zmaterializowało się w listopadzie 2017 roku w nowej ustawie o ordynacji wyborów lokalnych. Po drugie, spośród szczegółowych wyników znaczaca wage maja te wskazujące na silne, sensowne i teoretycznie uzasadnione związki między poczuciem sprawstwa a poziomem zakorzenienia społecznego jednostek, ich aktywnością publiczną oraz wizjami reprezentacji politycznej.

\section{BIBLIOGRAFIA}

Anderson, Christopher J. and Christine A. Guillory (1997). 'Political institutions and satisfaction with democracy: A cross-national analysis of consensus and majoritarian systems', American Political Science Review 91: 66-81.

Banducci, Susan A., Todd Donovan, and Jeffrey A. Karp (1999). 'Proportional representation and attitudes about politics: Evidence from New Zealand', Electoral Studies 18: 533-555.

Bandura, A. (1991). Social cognitive theory of self-regulation. Organizational Behavior and Human Decision Processes, 50: 248-287.

Downs, Anthony (1957). An economic theory of democracy. New York: Harper and Row

Duverger, Maurice (1954). Political parties. New York: Wiley.

Franklin, Charles H. and John E. Jackson (1983). The dynamics of party identification', American Political Science Review 77: 957-973.

Franklin, Mark N. with Cees van der Eijk, Diana Evans, Michael Fotos, Wolfgang Hirczy de Mino, Michael Marsh and Bernard Wessels (2004). Voter turnout and the dynamics of electoral competition in established democracies since 1945. New York: Cambridge University Press.

Franklin, Mark N. (1996). 'Electoral participation'. In Laurence LeDuc, Richard G. Niemi, and Pippa Norris (eds). Comparing democracies: Elections and voting in global perspective. Thousand Oaks, CA: Sage: 216-235.

Jackman, Robert W. and Ross A. Miller (1995). 'Voter turnout in the industrial democracies during the 1980s', Comparative Political Studies 27: 467-492.

Katz, Richard S. (1980). A theory of parties and electoral systems. Baltimore: Johns Hopkins University Press.

Ladner, Andrea and Henry Milner (1999). 'Do voters turn out more under proportional than majoritarian systems? The evidence from Swiss communal elections', Electoral Studies 18: 235-250. 
Leighley, Jan E. (1990) 'Social interaction and contextual influences on political Participation', American Politics Quarterly 18: 4: 459-475.

Morrell, M.E. (2005). Deliberation, democratic decision-making and internal political efficacy. Political Behavior, 27: 49-69.

Pingree, R.J. (2011). Effects of unresolved factual disputes in the news on epistemic political efficacy. Journal of Communication, 61, 22-47. doi:10.1111/jcom.2011.61.issue-1.

Powell, G. Bingham Jr. (1986). 'American voter turnout in comparative perspective', American Political Science Review 80: 17-44.

Pollock, III, P.H. (1983). The participatory consequences of internal and external political efficacy: A research note. The Western Political Quarterly, 400-409.

Rubin, D. (2006). Matched Sampling for Causal Effects. Cambridge: Cambridge University Press.

Taagepera, Rein and Mathew Soberg Shugart (1989). Seats and votes. The effects and determinants of electoral systems. New Haven: Yale University Press.

Verba, Sidney, Norman H. Nie, and Jae-On Kim (1978). Participation and political equality: A seven-nation comparison. Cambridge: Cambridge University Press. 